\title{
Spontaneous bacterial peritonitis: recent guidelines and beyond
}

\author{
R Wiest, ${ }^{1}$ A Krag, ${ }^{2}$ A Gerbes ${ }^{3}$
}

${ }^{1}$ Department for visceral surgery and medicine, University Hospital Bern, Switzerland ${ }^{2}$ Department of Gastroenterology, Hvidovre University Hospital, Copenhagen, Denmark ${ }^{3}$ Klinikum of the University of Munich, Munich, Germany

\section{Correspondence to}

Professor Dr Reiner Wiest, Department for visceral surgery and medicine, University Hospital Bern, 3010 Bern, Switzerland;

reiner.wiest@insel.ch

Published Online First 6 December 2011

\section{INTRODUCTION}

Spontaneous bacterial peritonitis (SBP) is the most frequent and life-threatening infection in patients with liver cirrhosis requiring prompt recognition and treatment. It is defined by the presence of $>250$ polymorphonuclear cells $(\mathrm{PMN}) / \mathrm{mm}^{3}$ in ascites in the absence of an intra-abdominal source of infection or malignancy. In this review we discuss the current opinions reflected by recent guidelines (American Association for the Study of Liver Diseases, European Association for the Study of the Liver, Deutsche Gesellschaft für Verdauungs- und Stoffwechselkrankheiten), ${ }^{1-4}$ with particular focus on controversial issues as well as open questions that need to be addressed in the future. First, diagnostic criteria and tools available for rapid and accurate diagnosis are reviewed. Second, since prophylaxis is of crucial relevance when trying to improve survival, we discuss who should be treated, when, how and for how long to prevent episodes of SBP. Identification of risk factors and individualisation of timing and selection of prophylactic measures are the key to success without major development of resistant bacteria. Finally, effective therapy is essential since treatment failure is associated with poor outcome. Since the emergence and spread of drug-resistant bacteria has accelerated, criteria for the choice of antibiotic regimen in the individual patient are pivotal for optimising therapy.

\section{EPIDEMIOLOGY AND PROGNOSIS OF SBP}

SBP is the most frequent bacterial infection in cirrhosis, accounting for $10-30 \%$ of all reported bacterial infections in hospitalised patients. ${ }^{5-7}$ In outpatients without symptoms the prevalence is low $\left(3.5 \%{ }^{8}\right.$ or lower $\left.{ }^{10}\right)$, but the prevalence increases in the nosocomial setting, ranging from $8 \%$ to $36 \%{ }^{11}{ }^{12}$ Bacterascites, defined as positive culture results but no increase in the PMN count in the ascitic fluid, occurs with a prevalence of $2-3 \%$ in outpatients ${ }^{8-10}$ and in up to $11 \%$ in hospitalised patients. ${ }^{11} 13$ In-hospital mortality for the first episode of SBP ranges from $10 \%$ to $50 \%$, depending on various risk factors. ${ }^{74-18}$ One-year mortality after a first episode of SBP has been reported to be $31 \%$ and $93 \% .^{8}{ }^{17}{ }^{19-21}$ In fact, the occurrence of SBP or other severe bacterial infections markedly worsens the prognosis in patients with cirrhosis and it has been proposed that a new prognostic stage of cirrhosis not reflected in current staging systems should be defined, the so-called 'critically ill cirrhotic'. ${ }^{22}$ Patients at this late stage have to be evaluated for the possibility of liver transplantation. Predictive factors reported for a poor prognosis in various cohorts of patients with SBP are summarised in figure 1 and include age, ${ }^{16} 20$ Child score, ${ }^{18} 2023$ intensive care, ${ }^{16} 18$ nosocomial origin, ${ }^{18}{ }^{24}$ hepatic encephalopathy, ${ }^{25}$ elevated serum creatinine and bilirubin, ${ }^{26}$ lack of infection resolution/need to escalate treatment and culture positivity ${ }^{27-29}$ as well as the presence of bacteraemia $^{30}$ and CARD15/NOD2 variants as a genetic risk factor. ${ }^{31}$ It is important to stress in this context that the only factors that are modifiable in this scenario are timely diagnosis and effective first-line treatment.

\section{Bacterial translocation (BT) and pathophysiology}

Bacterial translocation (BT) is the most common cause of SBP. ${ }^{32}{ }^{33}$ However, particularly in nosocomial SBP, other sources such as transient bacteraemia due to invasive procedures can lead to SBP. Limited BT to mesenteric lymph nodes (MLN) is a physiological phenomenon, whereas any increase in the rate and severity of BT may be deleterious for the patient and thus should be termed 'pathological BT'. Only a few intestinal bacteria are able to translocate into MLN, including Escherichia coli, Klebsiella pneumoniae and other Enterobacteriaceae. ${ }^{34}$ Interestingly, these species most frequently cause SBP, and DNA sequencing studies reveal genotypic identity of bacteria in MLN and ascites in the vast majority of cases. ${ }^{35} 36$ This suggests that pathological BT is the underlying cause and source of SBP in cirrhosis and supports the view that the route of pathological BT leading to SBP is largely lymphatic. Three factors have been implicated in the development of pathological BT in liver cirrhosis ${ }^{32}$ : (1) alterations in gut microbiota; (2) increased intestinal permeability; and (3) impaired immunity.

\section{Microbiota}

Liver cirrhosis is associated with distinct changes in faecal microbial composition ${ }^{37} 38$ including an increased prevalence of potentially pathogenic bacteria such as Enterobacteriaceae. Moreover, small intestinal bacterial overgrowth (SIBO), defined as $>10^{5}$ colony forming units $/ \mathrm{ml}$ jejunal aspirate and/or colonic-type species, is frequently present in advanced stages of liver cirrhosis and has been linked with pathological BT, SBP and endotoxinaemia. ${ }^{39-41}$ In cirrhosis, factors promoting these changes may include deficiencies in paneth cell defensins, ${ }^{41 a}$ reduced intestinal motility, decreased pancreatobiliary secretions and portal-hypertensive enteropathy. In experimental cirrhosis, in the absence of SIBO, BT occurs rarely $(0-11 \%)$ and at rates comparable to healthy 


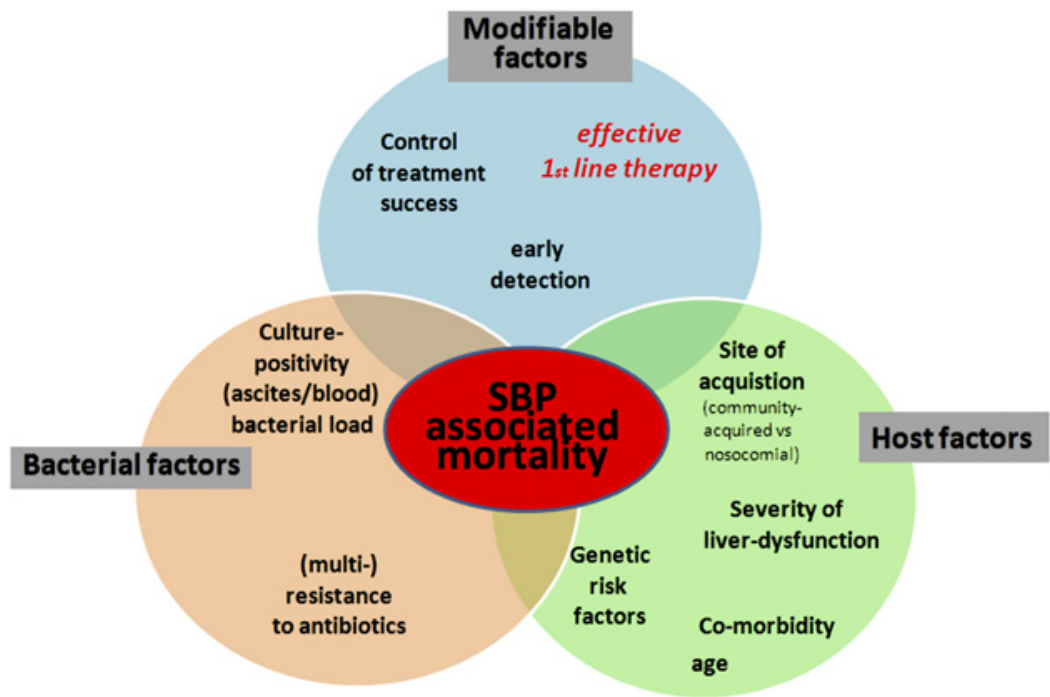

Figure 1 Spontanous bacterial peritonitis (SBP)-associated mortality. Reported risk factors for poor prognosis in SBP are categorised into fixed or modifiable factors as well as host and bacterial factors, respectively. The most relevant for survival is resolution of infection which is best influenced by effective first-line therapy since other factors are not modifiable. migration and accumulation in the peritoneal cavity combating invading bacteria depends on a number of factors. Resident macrophages are the first to phagocytose bacteria, they further help to attract PMN by release of chemotactic factors and activate complement. For instance, monocyte chemotactic protein 1 is one of the most potent chemokines, and a functional polymorphism has been proposed as a risk factor for SBP in alcoholic cirrhosis. ${ }^{45}$ A chemotactic gradient is necessary to achieve appropriate neutrophil recruitment into the peritoneal cavity. In fact, PMN chemoattractants such as zymosan are very effective in preventing the death of animals with $E$ coli-induced peritonitis when administered locally but not systemically. ${ }^{46}$ Unfortunately, little is known about the influx, efflux and kinetics of neutrophils in ascitic fluid in cirrhosis and its dependency on type, extent and duration of bacterial stimulus as well as host factors.

Besides influx of PMN, bacterial clearance is determined by the overall killing capacity which is dependent on opsonisation, burst activity and inflammatory response. A marked reduction in opsonic and bactericidial activity is well-known in cirrhosis. In particular, low C3 levels in cirrhotic ascites correlate strongly with opsonic activity ${ }^{47}$ and have been shown to predispose to SBP. ${ }^{48}$ However, the total protein content aslo mirrors opsonic activity and has been shown to be predictive of the development of SBP. ${ }^{49}$ At a protein level of $>1.5 \mathrm{~g} / \mathrm{dl}$ ascitic fluid, the incidence rates of SBP have been consistently reported to be lower than $1 \%$. In contrast, at protein levels $<1.5 \mathrm{~g} / \mathrm{dl}$ ascitic fluid, the risk of SBP increases, parallelling the decrease in protein content and reaching incidence rates of $27-41 \%$ at levels $<1.0 \mathrm{~g} / \mathrm{dl}^{19}{ }^{19} 51$ Other factors that may contribute but have not been addressed thoroughly include compartmentalisation via activation of coagulatory systems or the omentum (called the 'abdominal policeman') and visceral fat. The latter is a relevant source of adipokines known to modulate the inflammatory response. In fact, significant levels of, for example, adiponectin, visfatin and resistin are observed in ascites and the latter is increased in the presence of SBP. ${ }^{52}$

Local ascitic-peritoneal host defence in peritonitis The peritoneal cavity probably has the most severe lack of host defence compared with other compartments in decompensated cirrhosis. In fact, ascites per se may be considered a risk factor for the development of peritonitis. In healthy conditions, peritoneal host defence mechanisms are very efficient and intraperitoneal injection of various numbers of single organisms does not cause peritonitis unless adjuvant substances or ascites are present. ${ }^{44}$ In cirrhosis, deficiencies in local defence mechanisms against bacteria, including dysfunction of cellular and humoral immunity, limit peritoneal bacterial clearance.

Since the absolute number of $\mathrm{PMN}$ per $\mathrm{mm}^{3}$ ascitic fluid defines SBP, the mechanisms of chemotaxis mediating PMN influx into the peritoneal cavity are important. The degree of PMN

\section{Liver dysfunction and systemic risk factors}

Cirrhosis is accompanied by deficits in innate and adaptive intrahepatic, intestinal and systemic immunity. Patients with cirrhosis with decreased reticuloendothelial system (RES) activity develop SBP at a higher rate than those with close to normal RES activity. ${ }^{23}$ Accordingly, markers of advanced liver dysfunction have been identified as independent risk factors for a first episode of SBP. A bilirubin level of $>3.2 \mathrm{mg} / \mathrm{dl}$ and platelet count of $<98000 / \mathrm{mm}^{3}$ significantly increase the likelihood of $\mathrm{SBP}^{53}$ and each model for end-stage liver disease (MELD) point increases the risk of SBP by about $11 \% .{ }^{54}$ However, circulating mononuclear cells also present with alterations in Toll-like receptor $(\text { TLR })^{55}$ and HLA expression ${ }^{56} 57$ as well as reduced 
chemotactic, opsonic, phagocytic and killing capacity. ${ }^{58} 59$ Furthermore, genetic variants influencing host defence mechanisms such as CARD15/ NOD2 $2^{31}{ }^{60}$ and TLR2 ${ }^{61}$ have been reported to be associated with an enhanced probability of acquiring SBP. TLR2 polymorphisms and NOD2 variants seem to represent supplementary risk factors since the simultaneous presence of both unfavourable polymorphisms markedly increases the risk of SBP. ${ }^{61}$ This underlines the known interaction of NOD2 and TLRs, in particular the modulation of TLR2-dependent cytokine responses by NOD2. ${ }^{62}$

Medication can also affect the chances of developing SBP. The use of proton pump inhibitors (PPI) has been proposed to facilitate SIBO and thus to contribute to pathological BT. In fact, retrospective case-control studies reveal a potential association between the use of PPI and development of SBP. ${ }^{63}$ Considering the frequently inadequate overuse of PPI in patients with cirrhosis, we therefore recommend restricting their use to indications of proven benefit. In contrast, non-selective $\beta$-blockers (NSBB) may prevent SBP. ${ }^{65}{ }^{66}$ It is tempting to speculate that this benefit relates to an improvement in chemotaxis, proinflammatory cytokine release and killing capacity reported for $\beta$-adrenergic antagonists in various experimental settings. ${ }^{6768}$ Since the sympathetic nervous system affects PMN chemotaxis, the question arises as to how treatment with NSBB affects the validity of diagnosing SBP based on PMN count in the ascitic fluid.

\section{DIAGNOSIS OF SBP}

Symptoms and signs are frequently absent in patients with SBP, ${ }^{69}$ so a diagnostic paracentesis should be performed in all patients with ascites admitted to hospital regardless of whether or not there is clinical suspicion. Diagnosis should be prompt and treatment must not be delayed until the microbiology results are available. Thus, in all the available guidelines, diagnosis is based on a fixed defined cut-off PMN count in the ascitic fluid. ${ }^{1-4}$ In patients with haemorrhagic ascites (ie, red blood cell count $>10000 / \mathrm{mm}^{3}$ ), subtraction of one PMN per 250 red blood cells should be made to adjust for the presence of blood in ascites. Owing to the short lifespan of PMN, their ascitic count is independent of diuretics and/or other modulations of ascites volume. In contrast, lymphocytes which have a long lifespan increase in concentration during diuresis. $^{70}$ Moreover, differential diagnoses of predominant lymphocytosis in ascitic fluid include tuberculous peritonitis, neoplasms, congestive heart failure, pancreatitis and myxedema, but not usually SBP. PMN are therefore used to define SBP, and the greatest sensitivity is reached at a cut-off value of $250 \mathrm{PMN} / \mathrm{mm}^{3}$, although the best specificity has been reported with a cut-off of $500 \mathrm{PMN} /$ $\mathrm{mm}^{3}$. $^{71-74}$ However, since it is important not to miss a case of SBP, the most sensitive cut-off value is used. Nonetheless, this upper limit has been set quite arbitrarily since it was tested in the setting of culture-positive peritonitis. Thus, the range of $\mathrm{PMN}$ in truly non-infected ascites-that is, the ascitic PMN count that is clinically relevant for the patient-is not known. Moreover, SBP caused by Gram-positive cocci has been reported frequently to have a PMN count below the threshold of $250 / \mathrm{mm}^{3}$. ${ }^{75}$ Interestingly, bactDNA from Gram-negative bacteria in ascitic fluid is associated with a higher ascitic PMN count than bactDNA from Gram-positive bacteria, ${ }^{76}$ underscoring the differences in stimulatory capacity for PMN migration depending on the type of bacteria.

\section{Microscopy versus automated cell counter}

Ascitic PMN cell counts can be determined either by a traditional haematological method using a light microscope and a manual counting chamber or by automated cell counters. ${ }^{77-79}$ Current guidelines either do not state specifically the method to be used ${ }^{2}{ }^{4}$ or recommend microscopy as the preferred method. ${ }^{1}$ However, microscopic evaluation is labour-intensive, time-consuming and has high intraoperator and interoperator variability. In contrast, automated cell counters, if available, are easily accessible in emergencies and provide results within minutes at low cost. Their use has recently been validated in patients with cirrhotic ascites, ${ }^{77} 79$ revealing sufficient sensitivity for detection of SBP, and thus should be recommended. However, it is important to stress that not all automated cell counters fulfil the quality criteria. These include sufficient functional sensitivity, test precision and accuracy, particularly for automated leucocyte counts in ascites even with low cell concentrations (eg, XE-5000 (Sysmex, Mundelein, IL, USA), Advia 120 (Erlangen, Germany), Iris iQ200 (Chatsworth, CA, USA), CellDyn-4000 (Wiesbaden, Germany)).

None of the recent guidelines recommends the use of reagent test strips to assess leucocyte esterase activity of activated PMNs for the diagnosis of SBP owing to unacceptable rates of false negative results. ${ }^{80}$ However, most of the strips used to date have been developed for urinary tract infections with a threshold of $>50 \mathrm{PMN} / \mathrm{mm}^{3}$. 81 Recently, a reagent strip test has been calibrated for ascitic fluid with a cut-off of $250 \mathrm{PMN} / \mathrm{mm}^{3}{ }^{82}$ Validity scores achievable were reported to be $100 \%$ sensitivity and $100 \%$ negative predictive value. However, this needs to be confirmed in large multicentre trials and, furthermore, the test was not interpretable in bloody, chylous or bilious ascitic fluid.

\section{Bacterial DNA detection and culture techniques}

Detection of bacterial DNA (bactDNA) using various approaches has recently been proposed in the ascitic fluid of patients with cirrhosis. ${ }^{83-85}$ The advantage of such a system would be the immediate identification of the causative bacteria, thus enabling more accurately targeted antibiotic treatment. BactDNA is found in the ascitic fluid of about $40 \%$ of patients with cirrhosis, being derived mainly from Gram-negative bacteria. ${ }^{84} 85$ However, 
detection of bactDNA in ascites or serum was not associated with an enhanced incidence of SBP and does not appear to predict the development of bacterial infections. ${ }^{86}$

\section{Culture techniques}

Gram staining of peritoneal fluid is rarely helpful ${ }^{87}$ and is not recommended. In contrast, culture is the recommended procedure. Although only a few species and genera are found to cause SBP, more than 70 different microbial species have been isolated from the ascitic fluid of patients with bacteriologically-confirmed SBP. ${ }^{88}$ Classical culture techniques fail to grow bacteria in up to $65 \%$ of neutrocytic ascites. Bedside inoculation of ascites into blood culture bottles has been shown to increase the sensitivity to nearly $80 \% .^{89-91}$ In this regard, non-radiometric (eg, colorimetric BacTec) systems in particular have improved the time to diagnosis since they are faster than conventional blood culture bottles. ${ }^{89}$ Handling processes influence culture results and delay in transport increases false negative results. ${ }^{92}$ Separate and simultaneous blood cultures should be collected since $30-58 \%$ of SBP cases are associated with bacteraemia. ${ }^{30} 93$

\section{Other markers of inflammation and secondary peritonitis}

Other markers found to be indicative of SBP include ascitic $\mathrm{pH}$, lactate dehydrogenase, lactate (and corresponding arterial-ascitic gradients), but none of these is sufficiently predictive or discriminative and may be increased in malignancy-related ascites. $^{72} 749495$ Proteins such as granulocyte elastase $^{96}$ and lactoferrin ${ }^{97}$ released by PMN upon activation have likewise been shown to be increased in SBP. Lactoferrin was reported to give rates of sensitivity and specificity of $95.5 \%$ and $97 \%$, respectively, using a cut-off value of $242 \mathrm{ng} /$ $\mathrm{ml}$ and to decrease to below the cut-off value in patients responding to treatment. ${ }^{97}$ However, because of the small number of SBP cases in this investigation, confirmation is required in multicentre trials including assessment of its accuracy in haemorrhagic and coexisting malignant ascites.

Differentiation of SBP from secondary peritonitis due to perforation or inflammation of an intraabdominal organ is clinically very relevant as the associated mortality is exceedingly high. ${ }^{98}$ In fact, all patients with perforated secondary peritonitis not undergoing timely surgery have been reported to die during hospitalisation and, thus, delayed diagnostic investigation is fatal. However, the proposed criteria to suspect secondary peritonitis (eg, inadequate response to therapy, multiple organisms) $)^{13}$ are identified too late and therefore rapid and accurate 'chemical' parameters available at the time of paracentesis are needed. Parameters proposed by Runyon et al are neutrocytic ascites with at least two of the following three criteria: ascitic fluid total protein $>1 \mathrm{~g} / \mathrm{dl}$ (in contrast to $\mathrm{SBP}$ ), glucose $<50 \mathrm{mg} / \mathrm{dl}$ (due to bacterial glucose utilisation) or lactate dehydrogenase $>225 \mathrm{mU} /$ ml. ${ }^{99}$ The sensitivity of these criteria can be less than $68 \% 9899$ and thus can be optimised. In addition, Wu et al reported that ascitic fluid with either alkaline phosphatase $>240 \mathrm{U} / 1$ or carcinoembryonic antigen $>5 \mathrm{ng} / \mathrm{ml}$ in $80 \%$ of cases reflects peritonitis of secondary origin. ${ }^{100}$ Although no data are available on the diagnostic accuracy of the combined criteria (ie, those of either Wu et al or

\section{Box 1}

Key messages established unequivocally

- Clinical judgement does not rule out SBP and thus a diagnostic paracentesis should be performed in all patients with cirrhosis and ascites at hospital admission and/or in case of gastrointestinal bleeding, shock signs of inflammation, worsening of liver/renal function or hepatic encephalopathy.

- SBP is defined by $>250 \mathrm{PMN} / \mathrm{mm}^{3}$ and bacterascites by positive culture results of ascitic fluid in the absence of PMN $>250 / \mathrm{mm}^{3}$.

- Ascitic fluid culture is important to guide antibiotic therapy and should be performed in all patients before starting antibiotic treatment by inoculation of ascites into blood culture bottles at the patient's bedside.

\section{Controversial but proposed}

- PMN count in ascitic fluid can be determined either by microscope OR appropriate automated cell counters. Reagent strips currently cannot be recommended for rapid diagnosis of SBP but ascites-calibrated sticks may become available.

- Bacterial DNA is not useful in detecting or predicting the occurrence of SBP.

\section{Questions to be addressed in the future}

- Are there potential differences in the detection of SBP dependent on the use of $\beta$-blockers and the type of causative bacteria (Gram-positive vs Gram-negative)?

- Is the fixed cut-off PMN count used for defining SBP the best choice, or is the chemotactic capacity of each individual patient relevant?

- Which parameters are sufficiently sensitive to guide rapid imaging for detection of secondary peritonitis?

Runyon et al), they are likely to improve sensitivity and should be tested prospectively. In the meantime, we strongly recommend performing an abdominal CT scan as soon as any of these features are present. ${ }^{101}$

\section{TREATMENT OF SBP}

Treatment has to be started immediately after diagnosis of SBP and therefore is empirical since culture results are not available at this time point. The strain of bacteria causing SBP mainly depends on the site of acquisition. However, none of the international guidelines to date differentiates 
between nosocomial and community-acquired SBP with regard to the type of antibiotic regimen to use. This may be deleterious since nosocomial infections are associated with high rates of bacterial multiresistance and mortality (J G Acevedo, personal communication, 2009). ${ }^{24} 102$ Patients with cirrhosis are also at increased risk of healthcare-associated infections, ${ }^{103}$ but studies are needed to determine the associated risk for multiresistant bacteria causing SBP.

\section{Community-acquired SBP: complicated and uncomplicated cases}

Historically, Gram-negative bacteria-almost exclusively Enterobacteriaceae-have been isolated in the overwhelming majority of SBP cases. More recently, several studies have found an increasing rate of infections with Gram-positive bacteria and resistant microorganisms (J G Acevedo, personal communication, 2009). ${ }^{24} 29102$ However, in patients with no previous hospitalisation and no prior antibiotic treatment, the causative bacteria still usually belong to the easily treatable Enterobacteriaceae family of bacteria. Several antibiotics have been recommended for the initial treatment of SBP in these cases including cefotaxime or other third-generation cephalosporins, amoxicillin-clavulanic acid or quinolones. Although earlier trials have shown comparable efficacy of intravenous amoxicillin/clavulanic acid (1/0.2 g every $8 \mathrm{~h}$ ) and intravenous cefotaxime in the treatment of SBP, recent increases in resistance to aminopenicillin/ $\beta$-lactamase inhibitors ${ }^{104}$ may limit their usefulness. In patients presenting without complicating factors that may worsen therapeutic efficacy, oral treatment with quinolones appears sufficient in countries with a relatively low rate of quinoloneresistant strains of $E$ coli. Possible complicating factors include shock, ileus, gastrointestinal bleeding, severe hepatic encephalopathy or renal dysfunction (serum creatinine $>3 \mathrm{mg} / \mathrm{dl}$ ). ${ }^{105}$

\section{Nosocomial SBP: treatment failure, risk factors and recommendations}

In nosocomial SBP, use of the antibiotics recommended above (third-generation cephalosporins, amoxicillin/clavulanic acid or quinolones) has recently led to disappointing and unacceptably low rates of resolution (J G Acevedo, personal communication, 2009). ${ }^{29} 106$ Resistance to third-generation cephalosporins and quinolones has been reported to increase continuously and to reach levels of $23-44 \%$ and $38-50 \%$, respectively, in some institutions and countries (J G Acevedo, personal communication, 2009). ${ }^{24} 29106107$ In addition, the incidence of extended-spectrum $\beta$-lactamase (ESBL)-producing bacteria as well as multiresistant Gram-positive bacteria such as Enterococcus faecium or methicillin-resistant Staphylococcus aureus (MRSA) causing nosocomial SBP is alarming (table 1). MRSA has been found in $24-27 \%$ of cases of SBP, with detection of $S$ aureus in ascites several years ago. ${ }^{75} 112$ Fortunately, the numbers are decreasing in most European countries. ${ }^{113}$ In contrast, the Study for Monitoring Antimicrobial Resistance Trends reported that hospital-acquired ESBL-positive $E$ coli in any intra-abdominal infection have increased in Europe from 4.3\% in 2002 to $11.8 \%$ in $2008 .^{114} 115$ ESBLs cause resistance to various types of newer $\beta$-lactam antibiotics including third-generation cephalosporins and monobactams and, in addition, frequently also carry genes encoding resistance even to other antibiotics including quinolones, tetracyclines and antifolates. ${ }^{116}$ ESBL resistance genes/plasmids rapidly spread around the world, with foreign travel being associated with intestinal colonisation rates as high as 32\% in Asia (and 88\% specifically in India). ${ }^{117} 118$ Moreover, colonisation of these resistant organisms persists in a large proportion of patients for many months ${ }^{117}$ and any antibiotic treatment causes selective pressure, accelerating the clinical relevance of these bacteria. ${ }^{119}$ For SBP, ESBL-positive strains are not yet as frequent as in Asia but have been reported to cause up to $22 \%$ of nosocomial infections in Spain (J Fernandez, personal communication, 2010). However, among European countries and even among institutions in the same country, there are wide differences in resistance rates. For instance, for $E$ coli isolates, susceptibility rates of ciprofloxacin or ampicillin/ sulbactam are $90 \%$ and $65 \%$, respectively, in Estonia but are $52 \%$ and $32 \%$ in Turkey. ${ }^{114}$

The clinical relevance of these numbers is reflected in the associated morbidity, healthcareassociated costs and mortality. In a number of independent investigations, in-hospital mortality and/or 30-day mortality have been shown to be increased in nosocomial SBP caused by multiresistant bacteria compared with common bacteria (J G Acevedo, personal communication, 2009). ${ }^{75} 102106111$ In some series, most patients with SBP due to multiresistant bacteria died within the first 5 days after the diagnosis of SBP was made and, indeed, none of the patients with persistent infection survived. ${ }^{29}$ A meta-analysis of recently published data found a four times increased risk of mortality associated with bacterial resistance in SBP (figure 2). Nosocomial SBP due to ESBL strains or to multiresistant bacteria is often associated with a failure of first-line empirical antibiotic treatment. ${ }^{29} 102109$ Indeed, the need for escalation of treatment associated with poor survival is predictive of in-hospital mortality 24 and therefore must be avoided. The use of carbapenems and glycopeptides would be safest and easiest since no resistance has so far been reported in cases of SBP, but this is not practical and the choice of antibiotics needs to be stratified for parameters defining the risk of resistant bacteria. This includes host factors as well as validated knowledge of the resistance profile of bacteria acting in the setting in which the patient is diagnosed and treated. Reported independent risk factors for bacterial multiresistance are previous hospitalisation (particularly within 3 months and intensive care treatment) and prior prophylactic or therapeutic antibiotic treatment (figure 3). ${ }^{24} 29120121$ It is 


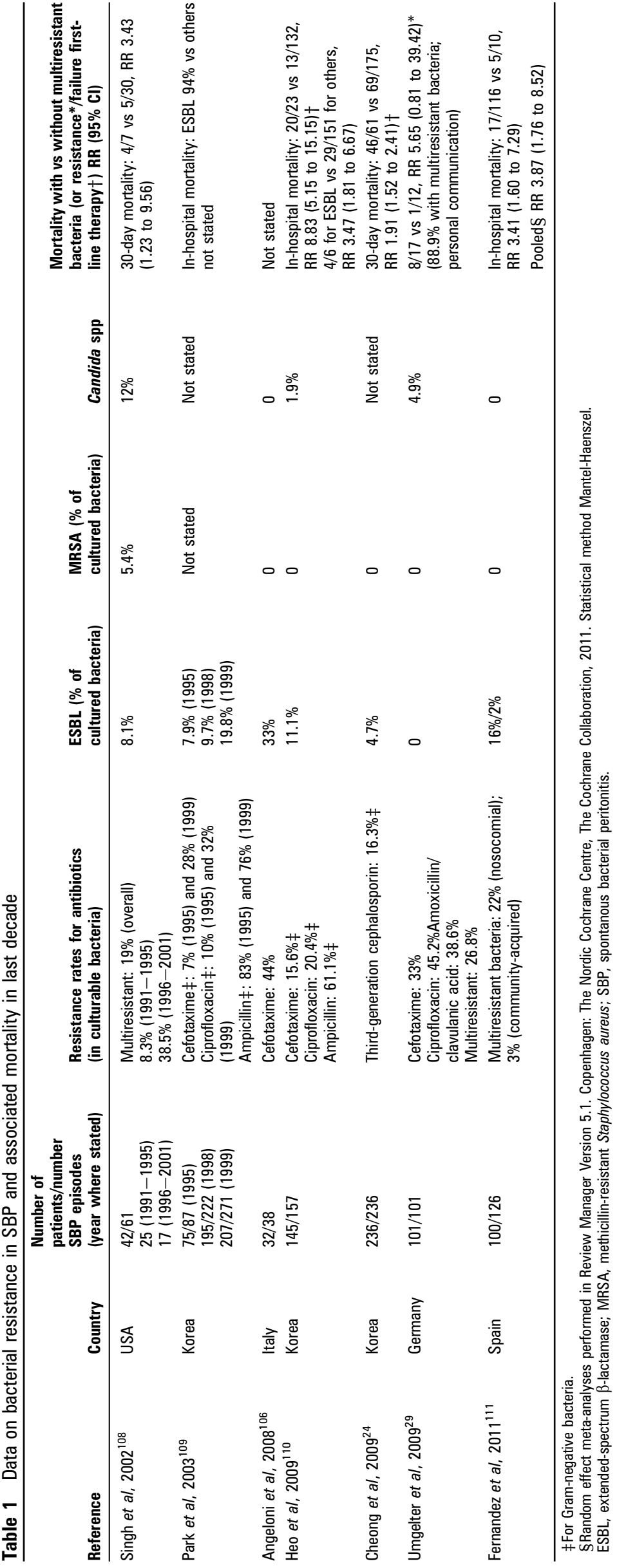

therefore suggested that, in patients with cirrhosis who develop nosocomial SBP and present with such risk factors, a more effective first-line empirical antibiotic therapy with a broader spectrum should be used, namely carbapenems. However, this regimen should be de-escalated as soon as possible if microbiological results reveal non-resistant easily treatable causative microorganisms. This minimises resistance selection pressure on the carbapenems and underlines the paramount importance of obtaining appropriate microbiological cultures. Global susceptibility statistics from intra-abdominal infections show that the susceptibilities of Gram-negative isolates to the carbapenems have remained stable over the past years, with $E$ coli and $K$ pneumoniae isolates, including ESBL-positive isolates, being $98-100 \%$ susceptible. ${ }^{122}$ Implementing carbapenems as first-line treatment in patients with nosocomial SBP with risk factors for multiresistant bacteria can therefore save lives. This has also been recommended in recent guidelines on the treatment of sepsis, ${ }^{123}$ aiming at rapid initiation of an antibiotic regimen likely to cover all expected causative microorganisms. The same should be even more true for patients with decompensated cirrhosis who have an enhanced proinflammatory response to bacterial stimuli ${ }^{124}$ and exhibit an increased susceptibility for any vasodilatory stimulus due to the already highly hyperdynamic splanchnic circulation. ${ }^{125}$

\section{Treatment of bacterascites}

It is controversial whether culture-positive results in the absence of an increased PMN count in the ascitic fluid require immediate initiation of antibiotic therapy. Some guidelines recommend antibiotic treatment only in patients with signs of infection or inflammation. ${ }^{4}$ Otherwise, a follow-up paracentesis should establish whether SBP is present (PMN count $>250 / \mathrm{mm}^{3}$ ) and thus whether treatment is indicated. However, this is based on a single-centre observational cohort study ${ }^{126}$ and has not been addressed prospectively. Until then we think that considering the lack of symptoms in a large number of cirrhotic patients even in presence of severe bacterial infection antibiotic treatment should be used in case of bacterascites.

\section{Use of albumin as adjuvant treatment}

In patients with cirrhosis with SBP, a prospective randomised comparative study reported that adjuvant administration of high-dose albumin $(1.5 \mathrm{~g} / \mathrm{kg}$ on day 1 and $1 \mathrm{~g} / \mathrm{kg}$ on day 3) with antibiotic treatment prevented worsening of renal function with a concomitant improvement in in-hospital and 3 -month survival. ${ }^{108}$ However, this regimen is mainly effective in high-risk patients characterised by serum bilirubin $>4 \mathrm{mg} / \mathrm{dl}$. In addition, in unselected patients with SBP, even low-dose albumin $(10 \mathrm{~g} /$ day on days $1-3)$ has been shown to reduce tumour necrosis factor and interleukin 6 levels in serum and ascites and to prevent increases in serum $\mathrm{NO}_{\mathrm{x}}$ induced by SBP. ${ }^{110}$ Therefore, future trials need to determine whether other patients with 


\begin{tabular}{|c|c|c|c|c|c|c|c|c|}
\hline Study or subgroup & \multicolumn{2}{|c|}{ Multiresistant bacteria } & \multicolumn{2}{|c|}{ Non-resistant bacteria } & Weight & $\begin{array}{c}\text { RR } \\
\text { M-H, Random, } 95 \% ~ C l\end{array}$ & \multirow{2}{*}{\multicolumn{2}{|c|}{$\begin{array}{c}\text { RR } \\
\text { M-H, Random, } 95 \% ~ C l\end{array}$}} \\
\hline Umgelter 2009 & 8 & 17 & 1 & 12 & $10.2 \%$ & $\frac{m-n \text {, kandom, }}{5.65(0.81 \text { to } 39.42)}$ & & \\
\hline Singh 2002 & 4 & 7 & $\begin{array}{l}1 \\
5\end{array}$ & 30 & $18.4 \%$ & 3.43 (1.23 to 9.56$)$ & & $\longrightarrow$ \\
\hline Heo 2009 & 20 & 23 & 13 & 132 & $23.8 \%$ & 8.83 (5.15 to 15.15$)$ & & \\
\hline Fernandez 2011 & 5 & 10 & 17 & 116 & $21.4 \%$ & 3.41 (1.60 to 7.29$)$ & & 一 \\
\hline Cheong 2009 & 46 & 61 & 69 & 175 & $26.2 \%$ & 1.91 (1.52 to 2.41$)$ & & $\Rightarrow$ \\
\hline Total $(95 \% \mathrm{Cl})$ & & 118 & & 465 & $100.0 \%$ & 3.87 (1.76 to 8.52 ) & & \\
\hline Total events & 83 & & 105 & & & & & \\
\hline $\begin{array}{l}\text { Heterogeneity: } \tau^{2}=0.6 \\
\text { Test for overall effect }\end{array}$ & $\begin{array}{l}0 ; \chi^{2}=28.29, d \\
Z=3.37(p=0 .\end{array}$ & $<0.00$ & $01) ; I^{2}=86 \%$ & & & & $\begin{array}{lc}0.02 & 0.1 \\
\text { Favours resistant }\end{array}$ & Favours $n$ \\
\hline
\end{tabular}

Figure 2 Meta-analysis of available data on the impact of multiresistant bacteria on mortality in cirrhosis.

cirrhosis could also benefit and to establish the dose and timing of albumin needed to give most benefit to the individual patient.

\section{Duration of treatment and control of treatment success}

Antibiotic treatment can safely be discontinued after the ascites PMN count has decreased to $<250 /$ $\mathrm{mm}^{3}$. In a comparative study, extension of treatment duration to 10 days was not superior to treatment for 5 days, ${ }^{127}$ and it is therefore recom-

\section{Box 2}

\section{Key messages established unequivocally}

- Empirical antibiotic therapy must be initiated immediately after the diagnosis of SBP is made.

- Uncomplicated community-acquired first SBP can be treated orally with quinolones in countries with low level quinolone resistance rates, otherwise third-generation cephalosporins should be used.

\section{Controversial but proposed}

- The choice of antibiotic regimen strongly needs to consider (a) the site of acquisition (community-acquired vs nosocomial), (b) prior antibiotic treatment and (c) local resistance profile. In cases of nosocomial SBP and either prior hospitalisation with antibiotic treatement or long-term antibiotic prophylaxis, the use of carbapenems is recommended.

- Albumin should be used as adjuvant treatment in patients with SBP and a high risk of worsening renal function.

\section{Questions to be addressed in the future}

- What are the individual risk factors for SBP due to multiresistant bacteria?

- Can asymptomatic bacterascites be left untreated?

- In which patients and with what schedule (dose and timing) should albumin be used as adjuvant treatment to optimise benefit?

- What change in PMN count in the ascitic fluid during antibiotic treatment defines best treatment failure and therefore the need to alter antibiotic treatment? mended that antibiotic therapy should be given for 5 days only. Moreover, current guidelines recommend changing treatment if the PMN count does not decrease by at least $25 \%$ compared with the pretreatment level after 2 days of antibiotic treatment. ${ }^{2}{ }^{3}$ However, this has not been established in a prospective manner and/or treatment algorithm. In fact, this is based on a retrospective analysis of the half-life of PMN in ascites after initiation of antibiotic treatment ${ }^{128}$ and the observation that the reduction in the ascites PMN count $48 \mathrm{~h}$ after initiation of antibiotic treatment is greater in survivors than in non-survivors $(92 \pm 9 \%$ vs $66 \pm 38 \%) .{ }^{129}$ There is therefore a clear need to establish the best time point and degree of reduction in PMN count to exclude accurately the chance of treatment failure in patients with SBP.

\section{PREVENTION OF SBP}

\section{Secondary and primary prophylaxis}

The efficacy and role of prophylactic antibiotics is indisputable in the setting of gastrointestinal bleeding and in patients who recover from an episode of SBP. ${ }^{1-4}$ For secondary prophylaxis, the evidence is strongest for norfloxacin. ${ }^{130}$ Some guidelines recommend the use of oral ciprofloxacin (750 mg once weekly) $)^{1}$ or trimethoprim/sulfamethoxazole as an alternative. ${ }^{13}$ However, the use of intermittent ciprofloxacin has been associated with

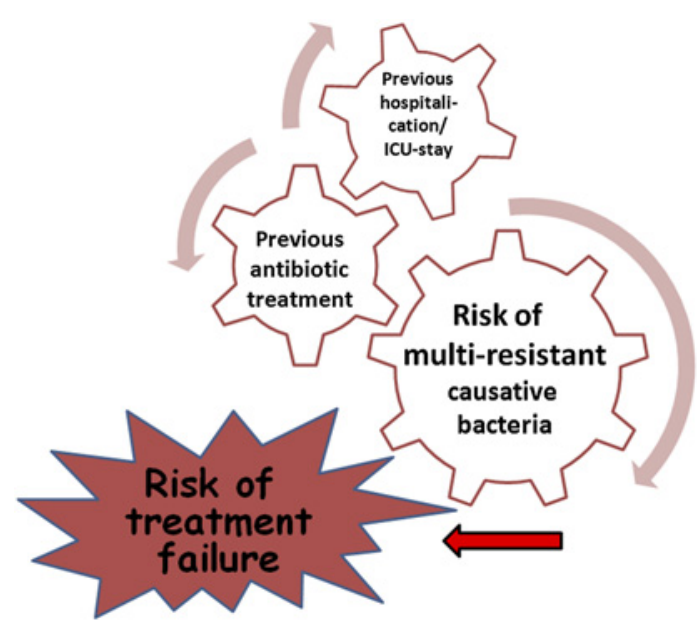

Figure 3 Key elements driving development of bacterial resistance and risk of treatment failure. 


\section{Recent advances in clinical practice}

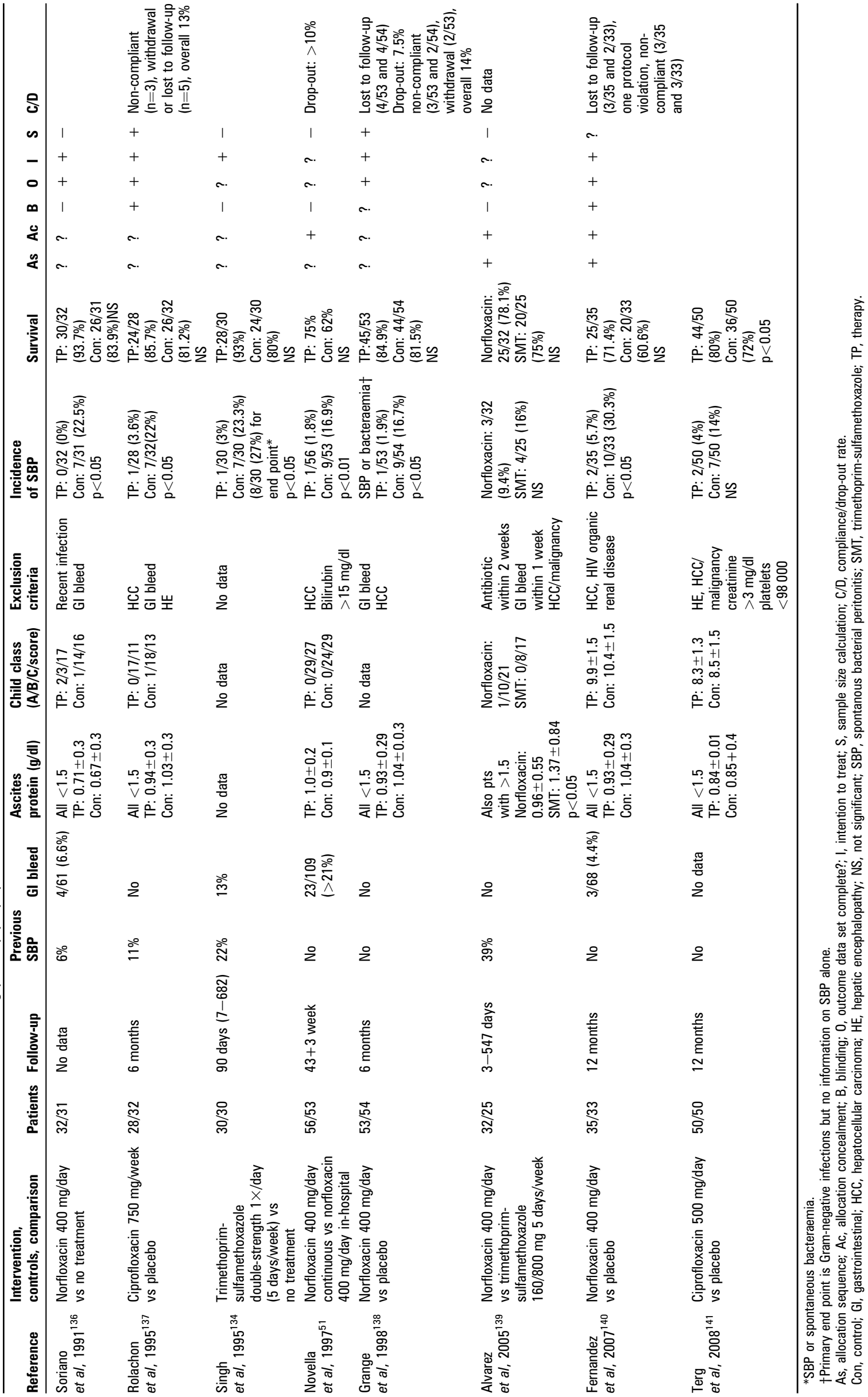


a higher rate of quinolone-resistant organisms ${ }^{131}$ and, in our view, should therefore be avoided. Data supporting the use of trimethoprim/sulfamethoxazole are weak, ${ }^{132}$ while its side effects are potentially dangerous and probably under-reported. ${ }^{133}$ Moreover, resistance to this class of antibiotics has increased to a degree that it is no longer recommended as the first-line choice for the empirical treatment of urinary tract infections in some countries. $^{134}$ In patients with cirrhosis with gastrointestinal haemorrhage, quinolones are most frequently used and have been found to decrease the incidence of severe infections (SBP and/or septicaemia) and mortality. However, in patients with bleeding necessitating invasive procedures, infections are increasingly caused by Gram-positive bacteria and intravenous delivery may be more appropriate than the oral route. In fact, the thirdgeneration cephalosporin ceftriaxone administered intravenously has been shown to be superior to oral norfloxacin in patients with advanced cirrhosis (ie, with at least two of the following: ascites, severe malnutrition, encephalopathy or bilirubin $>3 \mathrm{mg} / \mathrm{dl}) .{ }^{135}$

With regard to the use of antibiotics for primary prophylaxis in the setting of low protein ascites $(<1.5 \mathrm{mg} / \mathrm{dl})$, eight randomised controlled trials have been performed so far and are summarised in table 2. However, four trials also included patients with prior SBP ${ }^{132} 139142143$ and the remaining have recently been summarised in two meta-analyses. ${ }^{136} 137$ Surprisingly, these came to different conclusions, most likely due to erroneous data extraction. ${ }^{144}$ The study by Novella et al included a large number of patients with gastrointestinal bleeding, ${ }^{51}$ so only three trials truly focused on primary prophylaxis. ${ }^{140} 145146$ Here we present a meta-analysis of these three studies, which supports the efficacy of quinolones in the primary prevention of SBP (figure 4). ${ }^{140} 145146$ Corresponding numbers needed to treat (NNT) at 6 months to prevent one episode of SBP or death are 8.4 and 8.6, respectively. Even limiting the data to the two most recent and highest quality trials with follow-up for 12 months ${ }^{140} 145$ demonstrates significant preventive power for both end points: SBP (NNT 6.3) and mortality (NNT 7.3). Despite this evidence, most expert panels do not recommend the routine use of antibiotics in every patient with low protein ascites unless additional risk factors are present. ${ }^{134}$ This is based on the fear of accelerating selection of resistant bacteria by longterm use of broad-spectrum antibiotics ${ }^{119}$ and the lack of conclusive data supporting this approach. Indeed, primary prophylaxis in patients with low protein ascites without additional risk factors failed to reach statistical significance in preventing SBP, although reducing mortality was not calculated for this end point. ${ }^{140}$ In contrast, Fernandez et al further selected patients from the cohort with low protein ascites by the presence of one of the following criteria: (1) severe liver insufficiency, defined as Child score $\geq 9$ and serum bilirubin $\geq 3 \mathrm{mg} / \mathrm{dl}$; or (2) renal dysfunction defined as serum creatinine $\geq 1.2 \mathrm{mg} / \mathrm{dl}$, serum $\mathrm{BUN} \geq 25 \mathrm{mg} / \mathrm{dl}$ or serum sodium $\leq 130 \mathrm{mEq} / \mathrm{l}^{145}$ In this highly selected 'high-risk' group of patients with cirrhosis, norfloxacin reduced the 1-year probability of SBP from $61 \%$ to $7 \%(p<0.001)$ and improved the 1 -year survival probability from $48 \%$ to $60 \%(p<0.05)$.

\section{Meta-analysis: prevention of SBP in pure primary prophylactic RCT's}

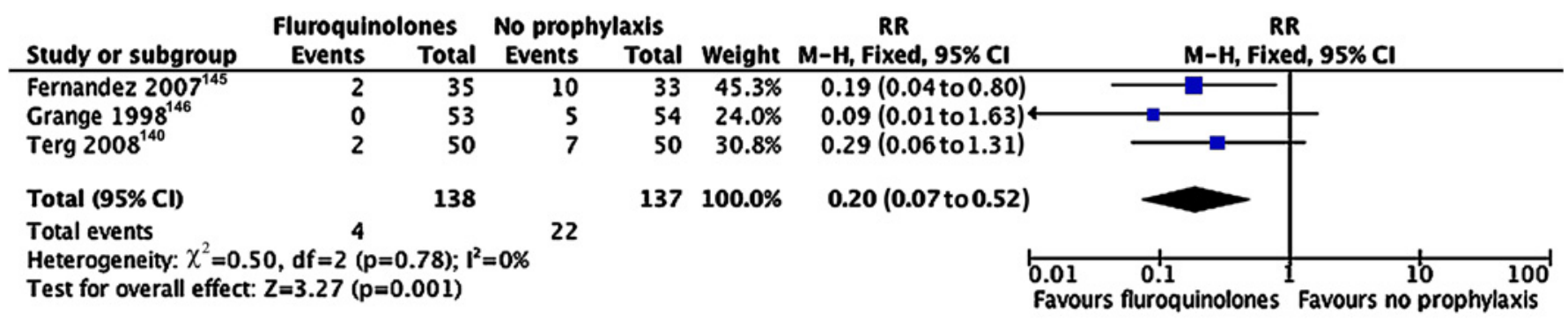

\section{Meta-analysis: prevention of mortality in pure primary prophylactic RCT's}

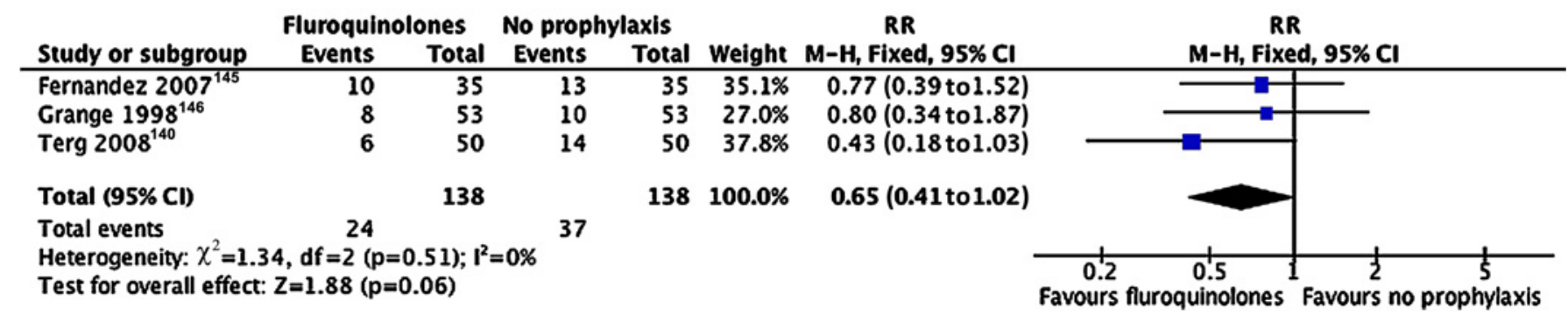

Figure 4 Meta-analysis of randomised controlled trials of primary prophylaxis for spontanous bacterial peritonitis (12 months follow-up). 
Nonetheless, guidelines state very cautiously that the long-term use of norfloxacin can be justified ${ }^{4}$ or should be considered in these selected patients. ${ }^{13}$ However, since this trial fulfils the highest quality criteria (Jadad score 5) and represents a well-defined group of patients, we consider the use of norfloxacin for primary prophylaxis as a standard of care procedure.

\section{Limitations in antibiotic prophylaxis and alternatives}

The longer the duration of antibiotic treatment, the greater is the risk for selection of resistant strains and the lower is the chance of reducing the incidence of SBP. In fact, survival advantage using norfloxacin as primary prophylaxis in highly selected patients is most marked during the first 3 months of treatment ( $94 \%$ vs $62 \%, p=0.003$ ) and decreases over time. ${ }^{138} 145$ We therefore propose that the use of norfloxacin for primary prophylaxis should also be considered in unselected patients with low protein ascites if liver transplantation is a realistic option within a few months. Although there are no long-term data, the same time course of antibiotic efficacy is likely to be present as in secondary prophylaxis. Its use is recommended to be continued until liver transplantation or until the disappearance of ascites (eg, in alcoholics stopping alcohol ingestion). ${ }^{2}{ }^{3}$ In any other case, antibiotic treatment guidelines support long-term use but, in our view, improvement in liver disease should lead to interruption of treatment.

Overall, the continuous use of a single antibiotic appears not to be the optimal solution and efforts should be made to seek alternatives which could include antibiotic cycling. The basic principle of cycling antibiotics is that bacteria acquiring resistance to the first course of treatment would remain susceptible to the second regimen, and so on. In this context, future trials should test the use of rifaximin since (a) it belongs to a different antibiotic class from the antibiotics tested prospectively so far; (b) it exerts a broad range of antimicrobial activity including Gram-positive bacteria ${ }^{141}$; (c) it appears to cause considerably less bacterial resistance ${ }^{147} 148$; and (d) it acts predominantly in the small intestine, ${ }^{147-149}$ the site of bacterial overgrowth in cirrhosis. Finally, as has been pointed out by others, ${ }^{150} 151$ effective non-antibiotic approaches in reducing the incidence of SBP represent the Holy Grail. Interestingly, a significant decrease in the incidence of postoperative infections has been reported in a cohort study of patients with cirrhosis treated with propranolol and ciprofloxacin compared with ciprofloxacin alone after laparoscopic surgery. ${ }^{152}$ Moreover, NSBB have been reported to ameliorate pathological BT in experimental cirrhosis. ${ }^{153}$ Finally, recent meta-analyses of available data indicate that NSBB lower the risk of SBP in patients with cirrhosis which may occur independently of the haemodynamic response achieved. ${ }^{6566}$ However, the use of NSBB in patients with refractory ascites has been suggested to worsen prognosis ${ }^{154} 155$ and to be associated with

\section{Box 3}

Key messages: established unequivocally

- In patients with gastrointestinal haemorrhage, antibiotic prophylaxis is mandatory using thirdgeneration cephalosporins (eg, ceftriaxone) in severe liver disease or quinolones in less severe and uncomplicated cases.

- Secondary prophylaxis is recommended after resolution of SBP with the strongest evidence supporting use of norfloxacin.

\section{Controversial but proposed}

- Primary prophylaxis can be justified in patients with low protein ascites $(<1.5 \mathrm{~g} / \mathrm{dl})$ and should be used in the presence of severe liver disease or renal impairment.

- Regimens applying antibiotics intermittently (eg once a week) should be avoided.

\section{Questions to be addressed in the future}

- Strong efforts should focus on effective prophylactic measures with low or zero risk for development of bacterial resistance including use of: (a) antibiotic cycling; (b) rifaximin; or (c) non-antibiotic treatments (eg, NSBB, prokinetics, probiotics, bile acids).

haemodynamic adverse effects after large-volume paracentesis. ${ }^{156}$ Future prospective trials therefore need to address these questions in detail in order to establish the use of NSBB in the right patient at the right time.

Cisapride, a serotonin 5-HT4 receptor agonist and intestinal prokinetic drug, has been shown to decrease SIBO and BT in experimental cirrhosis $^{41} 157$ but was abandoned due to cardiac side effects. Nonetheless, these encouraging results should stimulate human prospective trials investigating other prokinetics such as the new highly selective 5-HT4 receptor agonist prucalopride which showed no interaction at other receptor sites. ${ }^{158}$

Other promising approaches reported to ameliorate $\mathrm{BT}$ in experimental cirrhosis include orally administered conjugated bile acids, cholylsarcosine, ${ }^{159}$ insulin-like growth factor I) ${ }^{160}$ and anti-tumour necrosis factor. ${ }^{161}$ Probiotics have been reported to correct bacterial overgrowth, stabilise mucosal barrier function, improve neutrophil function and decrease BT in experimental liver failure. ${ }^{162} 163$ In patients with cirrhosis, symbiotic treatment significantly reduced endotoxin levels and improved the Child-Pugh functional class in nearly $50 \%$ of cases. ${ }^{164}$ Similarly, the addition of fibre to lactobacilli decreased postoperative bacterial infections after liver transplantation. ${ }^{165}$ Probiotics may even be helpful in limiting the development of bacterial resistance, and trials are ongoing to investigate their efficacy in eradicating carbapenem-resistant bacteria as well as the decolonisation of MRSA in carrier patients (NCT00722410/ NCT00941356). 
Acknowledgements The authors thank Professor Thomas Glueck (Hospital Trostberg, Germany) for helpful discussions, scientific advice and for reviewing the manuscript.

\section{Competing interests None.}

Contributors RW and AG wrote the manuscript. AK performed the statistical analysis and meta-analysis

Provenance and peer review Commissioned; externally peer reviewed.

\section{REFERENCES}

1. Fernandez J, Navasa M, Planas $R$, et al. Primary prophylaxis of spontaneous bacterial peritonitis delays hepatorenal syndrome and improves survival in cirrhosis. Gastroenterology 2007; 133:818-24.

2. Grange JD, Roulot D, Pelletier G, et al. Norfloxacin primary prophylaxis of bacterial infections in cirrhotic patients with ascites: a double-blind randomized trial [see comments]. J Hepatol 1998;29:430-6.

3. Terg R, Fassio E, Guevara M, et al. Ciprofloxacin in primary prophylaxis of spontaneous bacterial peritonitis: a randomized, placebo-controlled study. J Hepatol 2008;48:774-9.

4. Runyon BA. Management of adult patients with ascites due to cirrhosis: an update. Hepatology 2009;49:2087-107.

5. Fernandez J, Navasa M, Gomez J, et al. Bacterial infections in cirrhosis: epidemiological changes with invasive procedures and norfloxacin prophylaxis. Hepatology 2002;35:140-8.

6. Caly WR, Strauss E. A prospective study of bacterial infections in patients with cirrhosis. J Hepatol 1993;18:353-8.

7. Pinzello G, Simonetti RG, Craxi A, et al. Spontaneous bacterial peritonitis: a prospective investigation in predominantly nonalcoholic cirrhotic patients. Hepatology 1983;3:545-9.

8. Evans LT, Kim WR, Poterucha JJ, et al. Spontaneous bacterial peritonitis in asymptomatic outpatients with cirrhotic ascites. Hepatology 2003;37:897-901.

9. Castellote J, Girbau A, Maisterra S, et al. Spontaneous bacterial peritonitis and bacterascites prevalence in asymptomatic cirrhotic outpatients undergoing large-volume paracentesis. $J$ Gastroenterol Hepatol 2008;23:256-9.

10. Jeffries MA, Stern MA, Gunaratnam NT, et al. Unsuspected infection is infrequent in asymptomatic outpatients with refractory ascites undergoing therapeutic paracentesis. Am J Gastroenterol 1999;94:2972-6.

11. Conn HO, Fessel JM. Spontaneous bacterial peritonitis in cirrhosis: variations on a theme. Medicine (Baltimore) 1971; 50:161-97.

12. Rimola A, Garcia-Tsao G, Navasa M, et al. Diagnosis, treatment and prophylaxis of spontaneous bacterial peritonitis: a consensus document. International Ascites Club. J Hepatol

2000;32:142-53.

13. Chu CM, Chang KY, Liaw YF. Prevalence and prognostic significance of bacterascites in cirrhosis with ascites. Dig Dis Sci 1995; $40: 561-5$

14. Follo A, Llovet JM, Navasa M, et al. Renal impairment after spontaneous bacterial peritonitis in cirrhosis: incidence, clinical course, predictive factors and prognosis. Hepatology 1994:20:1495-501.

15. Nobre SR, Cabral JE, Gomes JJ, et al. In-hospital mortality in spontaneous bacterial peritonitis: a new predictive model. Eur $\mathrm{J}$ Gastroenterol Hepatol 2008;20:1176-81.

16. Thuluvath PJ, Morss S, Thompson R. Spontaneous bacterial peritonitis-in-hospital mortality, predictors of survival, and health care costs from 1988 to 1998. Am J Gastroenterol 2001;96:1232-6

17. Tito L, Rimola A, Gines $P$, et al. Recurrence of spontaneous bacterial peritonitis in cirrhosis: frequency and predictive factors. Hepatology 1988;8:27-31.

18. Toledo C, Salmeron JM, Rimola A, et al. Spontaneous bacterial peritonitis in cirrhosis: predictive factors of infection resolution and survival in patients treated with cefotaxime. Hepatology 1993:17:251-7.

19. Andreu M, Sola R, Sitges-Serra A, et al. Risk factors for spontaneous bacterial peritonitis in cirrhotic patients with ascites. Gastroenterol 1993:104:1133-8.

20. Silvain C, Besson I, Ingrand P, et al. Prognosis and long-term recurrence of spontaneous bacterial peritonitis in cirrhosis. $J$ Hepatol 1993;19:188-9.

21. Terg R, Levi D, Lopez P, et al. Analysis of clinical course and prognosis of culture-positive spontaneous bacterial peritonitis and neutrocytic ascites. Evidence of the same disease. Dig Dis Sci 1992;37:1499-504.

22. Arvaniti V, D'Amico G, Fede G, et al. Infections in patients with cirrhosis increase mortality four-fold and should be used in determining prognosis. Gastroenterology 2010;139:1246-56, 1256.e1-5.

23. Altman C, Grange JD, Amiot X, et al. Survival after a first episode of spontaneous bacterial peritonitis. Prognosis of potential candidates for orthotopic liver transplantation. J Gastroenterol Hepatol 1995;10:47-50.

24. Cheong HS, Kang Cl, Lee JA, et al. Clinical significance and outcome of nosocomial acquisition of spontaneous bacterial peritonitis in patients with liver cirrhosis. Clin Infect Dis 2009;48:1230-6.

25. Almdal TP, Skinhoj P. Spontaneous bacterial peritonitis in cirrhosis. Incidence, diagnosis, and prognosis. Scand J Gastroenterol 1987;22:295-300.

26. Terg R, Gadano A, Cartier M, et al. Serum creatinine and bilirubin predict renal failure and mortality in patients with spontaneous bacterial peritonitis: a retrospective study. Liver Int 2009;29:415-19.

27. Franca AV, De Souza JB, Silva CM, et al. Long-term prognosis of cirrhosis after spontaneous bacterial peritonitis treated with ceftriaxone. J Clin Gastroenterol 2001;33:295-8.

28. Kamani L, Mumtaz K, Ahmed US, et al. Outcomes in culture positive and culture negative ascitic fluid infection in patients with viral cirrhosis: cohort study. BMC Gastroenterol 2008;8:59.

29. Umgelter A, Reindl W, Miedaner M, et al. Failure of current antibiotic first-line regimens and mortality in hospitalized patients with spontaneous bacterial peritonitis. Infection 2009;37:2-8.

30. Cho JH, Park KH, Kim SH, et al. Bacteremia is a prognostic factor for poor outcome in spontaneous bacterial peritonitis. Scand J Infect Dis 2007;39:697-702.

31. Appenrodt B, Grunhage F, Gentemann MG, et al. Nucleotidebinding oligomerization domain containing 2 (NOD2) variants are genetic risk factors for death and spontaneous bacterial peritonitis in liver cirrhosis. Hepatology 2010;51:1327-33.

32. Wiest R, Garcia-Tsao G. Bacterial translocation (BT) in cirrhosis Hepatology 2005;41:422-33.

33. Wiest R. Role of bacterial infections for hepatorenal syndrome In: Gerbes A, ed. Frontiers in Gastrointestinal Research. Aszites, Hyponatremia and heptorenal syndrome. Basel, Switzerland Krager, 2010.

34. Wells CL. Relationship between intestinal microecology and the translocation of intestinal bacteria. Antonie Van Leeuwenhoek 1990;58:87-93.

35. Guarner C, Gonzalez-Navajas JM, Sanchez E, et al. The detection of bacterial DNA in blood of rats with CCl4-induced cirrhosis with ascites represents episodes of bacterial translocation. Hepatology 2006;44:633-9.

36. Llovet JM, Bartoli R, March F, et al. Translocated intestinal bacteria cause spontaneous bacterial peritonitis in cirrhotic rats: molecular epidemiologic evidence. J Hepatol 1998;28:307-13.

37. Chen Y, Yang F, Lu H, et al. Characterization of fecal microbial communities in patients with liver cirrhosis. Hepatology 2011;54:562-72.

38. Yan AW, Fouts DE, Brandl J, et al. Enteric dysbiosis associated with a mouse model of alcoholic liver disease. Hepatology 2011;53:96-105.

39. Bauer TM, Steinbruckner B, Brinkmann FE, et al. Small intestina bacterial overgrowth in patients with cirrhosis: prevalence and relation with spontaneous bacterial peritonitis. Am J Gastroenterol 2001;96:2962-7.

40. Guarner C, Runyon BA, Young S, et al. Intestinal bacterial overgrowth and bacterial translocation in cirrhotic rats with ascites. J Hepatol 1997;26:1372-8.

41. Pardo A, Bartoli R, Lorenzo-Zuniga V, et al. Effect of cisapride on intestinal bacterial overgrowth and bacterial translocation in cirrhosis. Hepatology 2000;31:858-63.

41a. Teltschik Z, Wiest R, Beisner J, et al. Intestinal bacterial translocation in cirrhotic rats is related to compromised Paneth cell antimicrobial host defence. Hepatology (in press).

42. Chiva M, Guarner C, Peralta C, et al. Intestinal mucosal oxidative damage and bacterial translocation in cirrhotic rats. Eur $\mathrm{J}$ Gastroenterol Hepatol 2003;15:145-50.

43. Ramachandran A, Prabhu R, Thomas $S$, et al. Intestinal mucosa alterations in experimental cirrhosis in the rat: role of oxygen free radicals. Hepatology 2002;35:622-9.

44. Dunn DL, Barke RA, Ahrenholz DH, et al. The adjuvant effect of peritoneal fluid in experimental peritonitis. Mechanism and clinical implications. Ann Surg 1984;199:37-43. 
45. Gabele E, Muhlbauer $\mathrm{M}$, Paulo $\mathrm{H}$, et al. Analysis of monocyte chemotactic protein-1 gene polymorphism in patients with spontaneous bacterial peritonitis. World J Gastroenterol 2009;15:5558-62.

46. Joyce LD, Hau T, Hoffman R, et al. Evaluation of the mechanism of zymosan-induced resistance to experimental peritonitis. Surgery 1978;83:717-25.

47. Runyon BA, Morrissey RL, Hoefs JC, et al. Opsonic activity of human ascitic fluid: a potentially important protective mechanism against spontaneous bacterial peritonitis. Hepatology 1985;5:634-7.

48. Such J, Guarner C, Enriquez J, et al. Low C3 in cirrhotic ascites predisposes to spontaneous bacterial peritonitis. J Hepatol 1988;6:80-4.

49. Runyon BA. Low-protein-concentration ascitic fluid is predisposed to spontaneous bacterial peritonitis. Gastroenterol 1986:91:1343-6.

50. Llach J, Rimola A, Navasa M, et al. Incidence and predictive factors of first episode of spontaneous bacterial peritonitis in cirrhosis with ascites: relevance of ascitic fluid protein concentration. Hepatology 1992;16:724-7.

51. Novella M, Sola R, Soriano G, et al. Continuous versus inpatient prophylaxis of the first episode of spontaneous bacterial peritonitis with norfloxacin. Hepatology 1997;25:532-6.

52. Wiest R, Leidl F, Kopp A, et al. Peritoneal fluid adipokines: ready for prime time? Eur J Clin Invest 2009;39:219-29.

53. Guarner C, Sola R, Soriano G, et al. Risk of a first community acquired spontaneous bacterial peritonitis in cirrhotics with low ascitic fluid protein levels. Gastroenterology 1999;117:414-19.

54. Obstein KL, Campbell MS, Reddy KR, et al. Association between model for end-stage liver disease and spontaneous bacterial peritonitis. Am J Gastroenterol 2007;102:2732-6.

55. Riordan SM, Skinner N, Nagree A, et al. Peripheral blood mononuclear cell expression of toll-like receptors and relation to cytokine levels in cirrhosis. Hepatology 2003:37:1154-64.

56. Wasmuth HE, Kunz D, Yagmur E, et al. Patients with acute on chronic liver failure display "sepsis-like" immune paralysis. $J$ Hepatol 2005:42:195-201.

57. Berres ML, Schnyder B, Yagmur E, et al. Longitudinal monocyte human leukocyte antigen-DR expression is a prognostic marker in critically ill patients with decompensated liver cirrhosis. Liver Int 2009;29:536-43

58. Hassner A, Kletter $Y$, Jedvab $M$, et al. Impaired monocyte function in liver cirrhosis. Lancet 1979:1:329-30.

59. Rajkovic IA, Williams R. Abnormalities of neutrophil phagocytosis, intracellular killing and metabolic activity in alcoholic cirrhosis and hepatitis. Hepatology 1986;6:252-62.

60. Bruns T, Peter J, Reuken PA, et al. NOD2 gene variants are a risk factor for culture-positive spontaneous bacterial peritonitis and monomicrobial bacterascites in cirrhosis. Liver Int 2011:10-3231.

61. Nischalke HD, Berger C, Aldenhoff K, et al. Toll-like receptor (TLR) 2 promotor and intron 2 polymorphisms are associated with increased risk for spontaneous bacterial peritonitis in liver cirrhosis. J Hepatol 2011;55:1010-16.

62. Netea MG, Ferwerda G, de Jong DJ, et al. Nucleotide-binding oligomerization domain-2 modulates specific TLR pathways for the induction of cytokine release. J Immunol 2005;174:6518-23.

63. Bajaj JS, Zadvornova Y, Heuman DM, et al. Association of proton pump inhibitor therapy with spontaneous bacterial peritonitis in cirrhotic patients with ascites. Am J Gastroenterol 2009;104:1130-4.

64. Trikudanathan G, Israel J, Cappa J, et al. Association between proton pump inhibitors and spontaneous bacterial peritonitis in cirrhotic patients - a systematic review and meta-analysis. Int $J$ Clin Pract 2011;65:674-8.

65. Senzolo $\mathbf{M}$, Cholongitas $E$, Burra $P$, et al. beta-Blockers protect against spontaneous bacterial peritonitis in cirrhotic patients: a meta-analysis. Liver Int 2009;29:1189-93.

66. Krag A, Wiest R, Albillos A, et al. Reduced mortality with non selective betablockers (NSBB) compared to banding is not related to prevention of bleeding or bleeding related mortality: a hypothesis for non-hemodynamic effects of NSBB. J Hepatol 2011;:54:S72.

67. Sanders VM, Straub RH. Norepinephrine, the beta-adrenergic receptor, and immunity. Brain Behav Immun 2002;16:290-332.

68. Worlicek M, Knebel K, Linde HJ, et al. Splanchnic sympathectomy prevents translocation and spreading of $E$ coli but not $S$ aureus in liver cirrhosis. Gut 2010;59:1127-34.

69. Chinnock B, Afarian $\mathrm{H}$, Minnigan $\mathrm{H}$, et al. Physician clinical impression does not rule out spontaneous bacterial peritonitis in patients undergoing emergency department paracentesis. Ann Emerg Med 2008;52:268-73

70. Hoefs JC. Increase in ascites white blood cell and protein concentrations during diuresis in patients with chronic liver disease. Hepatology 1981;1:249-54

71. Albillos A, Cuervas-Mons V, Millan I, et al. Ascitic fluid polymorphonuclear cell count and serum to ascites albumin gradient in the diagnosis of bacterial peritonitis. Gastroenterology 1990:98:134-40.

72. Garcia-Tsao G, Conn HO, Lerner E. The diagnosis of bacterial peritonitis: comparison of $\mathrm{pH}$, lactate concentration and leukocyte count. Hepatology 1985;5:91-6.

73. Stassen WN, McCullough AJ, Bacon BR, et al. Immediate diagnostic criteria for bacterial infection of ascitic fluid. Evaluation of ascitic fluid polymorphonuclear leukocyte count, $\mathrm{pH}$, and lactate concentration, alone and in combination. Gastroenterology 1986;90:1247-54

74. Yang CY, Liaw YF, Chu CM, et al. White count, pH and lactate in ascites in the diagnosis of spontaneous bacterial peritonitis. Hepatology 1985;5:85-90.

75. Campillo B, Richardet JP, Kheo T, et al. Nosocomial spontaneous bacterial peritonitis and bacteremia in cirrhotic patients: impact of isolate type on prognosis and characteristics of infection. Clin Infect Dis 2002;35:1-10.

76. Gonzalez-Navajas JM, Bellot P, Frances R, et al. Presence of bacterial-DNA in cirrhosis identifies a subgroup of patients with marked inflammatory response not related to endotoxin. $J$ Hepatol 2008:48:61-7.

77. Angeloni S, Nicolini G, Merli M, et al. Validation of automated blood cell counter for the determination of polymorphonuclear cell count in the ascitic fluid of cirrhotic patients with or without spontaneous bacterial peritonitis. Am J Gastroenterol 2003:98:1844-8.

78. Riggio 0, Angeloni S, Parente A, et al. Accuracy of the automated cell counters for management of spontaneous bacterial peritonitis. World J Gastroenterol 2008;14:5689-94.

79. Cereto F, Genesca J, Segura R. Validation of automated blood cell counters for the diagnosis of spontaneous bacterial peritonitis. Am J Gastroenterol 2004:99:1400.

80. Nousbaum JB, Cadranel JF, Nahon P, et al. Diagnostic accuracy of the Multistix 8 SG reagent strip in diagnosis of spontaneous bacterial peritonitis. Hepatology 2007;45:1275-81.

81. Hiscoke C, Yoxall H, Greig D, et al. Validation of a method for the rapid diagnosis of urinary tract infection suitable for use in genera practice. Br J Gen Pract 1990;40:403-5.

82. Mendler $\mathbf{M H}$, Agarwal A, Trimzi M, et al. A new highly sensitive point of care screen for spontaneous bacterial peritonitis using the leukocyte esterase method. J Hepatol 2010;53:477-83.

83. Bruns T, Sachse S, Straube E, et al. Identification of bacterial DNA in neutrocytic and non-neutrocytic cirrhotic ascites by means of a multiplex polymerase chain reaction. Liver Int 2009;29:1206-14.

84. Frances $\mathbf{R}$, Benlloch S, Zapater $\mathrm{P}$, et al. A sequential study of serum bacterial DNA in patients with advanced cirrhosis and ascites. Hepatology 2004;39:484-91.

85. Frances R, Zapater P, Gonzalez-Navajas JM, et al. Bacterial DNA in patients with cirrhosis and noninfected ascites mimics the soluble immune response established in patients with spontaneous bacterial peritonitis. Hepatology 2008;47:978-85.

86. Zapater P, Frances R, Gonzalez-Navajas JM, et al. Serum and ascitic fluid bacterial DNA: a new independent prognostic factor in noninfected patients with cirrhosis. Hepatology 2008;48:1924-31.

87. Chinnock B, Fox C, Hendey GW. Gram's stain of peritoneal fluid is rarely helpful in the evaluation of the ascites patient. Ann Emerg Med 2009;54:78-82.

88. Conn HO. Unusual presentations of SBP. In: Conn HO, Rodes J Navasa M, eds. London: Informa Healthcare, 2000:47-74.

89. Ortiz J, Soriano G, Coll P, et al. Early microbiologic diagnosis of spontaneous bacterial peritonitis with BacT/ALERT. J Hepatol 1997;26:839-44.

90. Siersema PD, de Marie S, van Zeijl JH, et al. Blood culture bottles are superior to lysis-centrifugation tubes for bacteriological diagnosis of spontaneous bacterial peritonitis. $J$ Clin Microbiol 1992;30:667-9.

91. Castellote $\mathbf{J}$, Xiol X, Verdaguer $\mathrm{R}$, et al. Comparison of two ascitic fluid culture methods in cirrhotic patients with spontaneous bacterial peritonitis. Am J Gastroenterol 1990;85:1605-8.

92. Klaerner HG, Eschenbach U, Kamereck K, et al. Failure of an automated blood culture system to detect nonfermentative gramnegative bacteria. J Clin Microbiol 2000;38:1036-41. 
93. Pelletier G, Salmon D, Ink 0, et al. Culture-negative neutrocytic ascites: a less severe variant of spontaneous bacterial peritonitis. J Hepatol 1990;10:327-31.

94. Gerbes AL, Jungst D, Xie YN, et al. Ascitic fluid analysis for the differentiation of malignancy-related and nonmalignant ascites. Proposal of a diagnostic sequence. Cancer 1991:68:1808-14.

95. Wang SS, Lu CW, Chao Y, et al. Malignancy-related ascites: a diagnostic pitfall of spontaneous bacterial peritonitis by ascitic fluid polymorphonuclear cell count. J Hepatol 1994;20:79-84.

96. Casafont F, Rivero M, Fernandez MD, et al. Granulocyte elastase in cirrhotic patients with spontaneous bacterial peritonitis. Dig Dis Sci 1999;44:1985-9.

97. Parsi MA, Saadeh SN, Zein NN, et al. Ascitic fluid lactoferrin for diagnosis of spontaneous bacterial peritonitis. Gastroenterology 2008; 135:803-7.

98. Soriano G, Castellote J, Alvarez CE, et al. Secondary bacterial peritonitis in cirrhosis: a retrospective study of clinical and analytical characteristics, diagnosis and management. J Hepatol 2009;52:39-44.

99. Runyon BA, Hoefs JC. Ascitic fluid analysis in the differentiation of spontaneous bacterial peritonitis from gastrointestinal tract perforation into ascitic fluid. Hepatology 1984:4:447-50.

100. Wu SS, Lin OS, Chen YY, et al. Ascitic fluid carcinoembryonic antigen and alkaline phosphatase levels for the differentiation of primary from secondary bacterial peritonitis with intestinal perforation. J Hepatol 2001;34:215-21.

101. Wiest R, Schoelmerich J. Secondary peritonitis in cirrhosis: "Oil in fire". J Hepatol 2009;52:7-9.

102. Song $\mathbf{K H}$, Jeon JH, Park WB, et al. Clinical outcomes of spontaneous bacterial peritonitis due to extended-spectrum betalactamase-producing Escherichia coli and Klebsiella species: a retrospective matched case-control study. BMC Infect Dis 2009; $9: 41$.

103. Merli M, Lucidi C, Giannelli V, et al. Cirrhotic patients are at risk for health care-associated bacterial infections. Clin Gastroenterol Hepatol 2010;8:979-85.

104. Kresken M, Hafner D, Schmitz FJ, et al. Resistenzsituation bei klinisch wichtigen Infektionserregern gegenüber Antibiotika in Deutschland und im mitteleuropäischen Raum. 2010. http:// www.p-e-g.org

105. Navasa M, Follo A, Llovet JM, et al. Randomized, comparative study of oral ofloxacin versus intravenous cefotaxime in spontaneous bacterial peritonitis [see comments]. Gastroenterology 1996;111:1011-17.

106. Angeloni S, Leboffe C, Parente A, et al. Efficacy of current guidelines for the treatment of spontaneous bacterial peritonitis in the clinical practice. World J Gastroenterol 2008; 14:2757-62.

107. Castellote J, Ariza X, Girbau A, et al. Antibiotic-resistant bacteria in spontanous bacterial peritonitis. Is it time to change? $J$ Hepatol 2010;52:S69.

108. Singh N, Wagener MM, Gayowski T. Changing epidemiology and predictors of mortality in patients with spontaneous bacterial peritonitis at a liver transplant unit. Clin Microbiol Infect 2003:9:531-7.

109. Park YH, Lee HC, Song HG, et al. Recent increase in antibioticresistant microorganisms in patients with spontaneous bacterial peritonitis adversely affects the clinical outcome in Korea. $J$ Gastroenterol Hepatol 2003;18:927-33.

110. Heo J, Seo YS, Yim HJ, et al. Clinical features and prognosis of spontaneous bacterial peritonitis in korean patients with liver cirrhosis: a multicenter retrospective study. Gut Liver 2009:3:197-204.

111. Campillo B, Dupeyron C, Richardet JP. Epidemiology of hospitalacquired infections in cirrhotic patients: effect of carriage of methicillin-resistant Staphylococcus aureus and influence of previous antibiotic therapy and norfloxacin prophylaxis. Epidemiol Infect 2001:127:443-50.

112. Piroth L, Pechinot A, Minello A, et al. Bacterial epidemiology and antimicrobial resistance in ascitic fluid: a 2-year retrospective study. Scand J Infect Dis 2009:41:847-51.

113. Kock R, Becker K, Cookson B, et al. Methicillin-resistant Staphylococcus aureus (MRSA): burden of disease and control challenges in Europe. Euro Surveill 2010;15:19688.

114. Hawser SP, Bouchillon SK, Hoban DJ, et al. Incidence and antimicrobial susceptibility of Escherichia coli and Klebsiella pneumoniae with extended-spectrum beta-lactamases in community- and hospital-associated intra-abdominal infections in Europe: results of the 2008 Study for Monitoring Antimicrobial Resistance Trends (SMART). Antimicrob Agents Chemother 2010;54:3043-6.
115. Coque TM, Baquero F, Canton R. Increasing prevalence of ESBLproducing Enterobacteriaceae in Europe. Euro Surveill 2008:13:19044.

116. Pitout JD, Laupland KB. Extended-spectrum beta-lactamaseproducing Enterobacteriaceae: an emerging public-health concern. Lancet Infect Dis 2008;8:159-66.

117. Tangden T, Cars O, Melhus A, et al. Foreign travel is a major risk factor for colonization with Escherichia coli producing CTX-M-type extended-spectrum beta-lactamases: a prospective study with Swedish volunteers. Antimicrob Agents Chemother 2010;54:3564-8.

118. Walsh TR, Weeks J, Livermore DM, et al. Dissemination of NDM-1 positive bacteria in the New Delhi environment and its implications for human health: an environmental point prevalence study. Lancet Infect Dis 2011;11:355-62.

119. World Health Organisation. Combat Drug Resistance: No Action Today Means No Cure Tomorrow. World Health Day 2011, 2011. http://www.who.int/mediacentre/multimedia/podcasts/en/

120. Rodriguez-Bano J, Picon E, Gijon P, et al. Risk factors and prognosis of nosocomial bloodstream infections caused by extended-spectrum-beta-lactamase-producing Escherichia coli. J Clin Microbiol 2010;48:1726-31.

121. Rodriguez-Bano J, Picon E, Gijon P, et al. Community-onset bacteremia due to extended-spectrum beta-lactamase-producing Escherichia coli: risk factors and prognosis. Clin Infect Dis 2010;50:40-8.

122. Hoban DJ, Bouchillon SK, Hawser SP, et al. Susceptibility of gram-negative pathogens isolated from patients with complicated intra-abdominal infections in the United States, 2007-2008: results of the Study for Monitoring Antimicrobial Resistance Trends (SMART). Antimicrob Agents Chemother 2010;54:3031-4.

123. Capp R, Chang Y, Brown DF. Effective Antibiotic Treatment Prescribed by Emergency Physicians in Patients Admitted to the Intensive Care Unit with Severe Sepsis or Septic Shock: Where is the Gap? J Emerg Med. Published Online First: 1 March 2011. PMID: 21371846.

124. Deviere J, Content J, Denys C, et al. Excessive in vitro bacteria lipopolysaccharide-induced production on monokines in cirrhosis. Hepatology 1990;11:628-34.

125. Wiest R, Das S, Cadelina G, et al. Bacterial translocation in cirrhotic rats stimulates eNOS-derived NO production and impairs mesenteric vascular contractility. J Clin Invest 1999;104:1223-33.

126. Runyon BA. Monomicrobial nonneutrocytic bacterascites: a variant of spontaneous bacterial peritonitis. Hepatology 1990;12:710-15.

127. Runyon BA, McHutchison JG, Antillon MR, et al. Short-course versus long-course antibiotic treatment of spontaneous bacteria peritonitis. A randomized controlled study of 100 patients. Gastroenterology 1991:100:1737-42.

128. Runyon BA, Hoefs JC. Spontaneous vs secondary bacterial peritonitis. Differentiation by response of ascitic fluid neutrophil count to antimicrobial therapy. Arch Intern Med 1986; 146:1563-5

129. Fong TL, Akriviadis EA, Runyon BA, et al. Polymorphonuclear cell count response and duration of antibiotic therapy in spontaneous bacterial peritonitis. Hepatology 1989;9:423-6.

130. Gines P, Rimola A, Planas R, et al. Norfloxacin prevents spontaneous bacterial peritonitis recurrence in cirrhosis: results of a double-blind, placebo- controlled trial. Hepatology 1990:12:716-24.

131. Terg R, Llano K, Cobas SM, et al. Effects of oral ciprofloxacin on aerobic gram-negative fecal flora in patients with cirrhosis: results of short- and long-term administration, with daily and weekly dosages. J Hepatol 1998;29:437-42.

132. Singh N, Gayowski T, Yu VL, et al. Trimethoprimsulfamethoxazole for the prevention of spontaneous bacterial peritonitis in cirrhosis: a randomized trial. Ann Intern Med 1995:122:595-8.

133. Nunnari G, Celesia BM, Bellissimo F, et al. Trimethoprimsulfamethoxazole-associated severe hypoglycaemia: a sulfonylurealike effect. Eur Rev Med Pharmacol Sci 2010;14:1015-18.

134. Wagenlehner FM, Schmiemann G, Hoyme U, et al. [National S3 guideline on uncomplicated urinary tract infection: recommendations for treatment and management of uncomplicated community-acquired bacterial urinary tract infections in adult patients] (In German). Urologe A 2011:50:153-69.

135. Fernandez J, Ruiz d A, Gomez C, et al. Norfloxacin vs ceftriaxone in the prophylaxis of infections in patients with advanced cirrhosis and hemorrhage. Gastroenterology 2006;131:1049-56. 
136. Saab S, Hernandez JC, Chi AC, et al. Oral antibiotic prophylaxis reduces spontaneous bacterial peritonitis occurrence and improves short-term survival in cirrhosis: a meta-analysis. $\mathrm{Am} \mathrm{J}$ Gastroenterol 2009:104:993-1001.

137. Loomba R, Wesley R, Bain A, et al. Role of fluoroquinolones in the primary prophylaxis of spontaneous bacterial peritonitis: meta-analysis. Clin Gastroenterol Hepatol 2009;7:487-93.

138. Runyon BA. A pill a day can improve survival in patients with advanced cirrhosis. Gastroenterology 2007:133:1029-31.

139. Soriano G, Guarner C, Teixido M, et al. Selective intestinal decontamination prevents spontaneous bacterial peritonitis. Gastroenterology 1991;100:477-81.

140. Terg R, Fassio E, Guevara M, et al. Ciprofloxacin in primary prophylaxis of spontaneous bacterial peritonitis: a randomized, placebo-controlled study. J Hepatol 2008;48:774-9.

141. Koo HL, Dupont HL. Rifaximin: a unique gastrointestinal-selective antibiotic for enteric diseases. Curr Opin Gastroenterol 2010;26:17-25

142. Alvarez RF, Mattos AA, Correa EB, et al. Trimethoprimsulfamethoxazole versus norfloxacin in the prophylaxis of spontaneous bacterial peritonitis in cirrhosis. Arq Gastroenterol 2005:42:256-62

143. Rolachon A, Cordier L, Bacq Y, et al. Ciprofloxacin and long-term prevention of spontaneous bacterial peritonitis: results of a prospective controlled trial. Hepatology 1995;22:1171-4

144. Krag A, Wiest R, Gluud LL. Fluoroquinolones in the primary prophylaxis of spontaneous bacterial peritonitis. Am J Gastroenterol 2010;105:1444-5.

145. Fernandez J, Navasa M, Planas R, et al. Primary prophylaxis of spontaneous bacterial peritonitis delays hepatorenal syndrome and improves survival in cirrhosis. Gastroenterology 2007:133:818-24.

146. Grange JD, Roulot D, Pelletier G, et al. Norfloxacin primary prophylaxis of bacterial infections in cirrhotic patients with ascites: a double-blind randomized trial [see comments]. $J$ Hepatol 1998;29:430-6.

147. Dupont HL, Jiang ZD, Okhuysen PC, et al. A randomized, doubleblind, placebo-controlled trial of rifaximin to prevent travelers diarrhea. Ann Intern Med 2005;142:805-12.

148. Dupont HL, Jiang ZD. Influence of rifaximin treatment on the susceptibility of intestinal Gram-negative flora and enterococci. Clin Microbiol Infect 2004;10:1009-11.

149. Darkoh C, Lichtenberger LM, Ajami N, et al. Bile acids improve the antimicrobial effect of rifaximin. Antimicrob Agents Chemother 2010;54:3618-24.

150. Garcia-Tsao G. Bacterial infections in cirrhosis: treatment and prophylaxis. J Hepatol 2005;42(Suppl 1):S85-92.
151. Riordan SM, Williams R. The intestinal flora and bacteria infection in cirrhosis. J Hepatol 2006;45:744-57.

152. Chelarescu 0, Chelarescu D, Ticovenau E, et al. Propranolol administration on post surgical infections in cirrhotic patients. J.Hepatol 2003;38:A173, (Abstract)

153. Perez-Paramo M, Munoz J, Albillos A, et al. Effect of propranolol on the factors promoting bacterial translocation in cirrhotic rats with ascites. Hepatology 2000;31:43-8.

154. Serste T, Melot C. Francoz C, et al. Deleterious effects of betablockers on survival in patients with cirrhosis and refractory ascites. Hepatology 2010;52:1017-22.

155. Angeli P. beta-Blockers and refractory ascites in cirrhosis: the message of a team of true scientists. J Hepatol 2011;55:743-4.

156. Serste T, Francoz C, Durand F, et al. Beta-blockers cause paracentesis-induced circulatory dysfunction in patients with cirrhosis and refractory ascites: a cross-over study. J Hepatol 2011:55:794-9.

157. Zhang SC, Wang W, Ren WY, et al. Effect of cisapride on intestinal bacterial and endotoxin translocation in cirrhosis. World J Gastroenterol 2003:9:534-8.

158. Tack J, van Outryve M, Beyens G, et al. Prucalopride (Resolor) in the treatment of severe chronic constipation in patients dissatisfied with laxatives. Gut 2009:58:357-65.

159. Lorenzo-Zuniga V, Bartoli R, Planas R, et al. Oral bile acids reduce bacterial overgrowth, bacterial translocation, and endotoxemia in cirrhotic rats. Hepatology 2003;37:551-7.

160. Lorenzo-Zuniga V, Rodriguez-Ortigosa CM, Bartoli R, et al. Insulin-like growth factor-I improves intestinal barrier function in cirrhotic rats. Gut 2006;55:1306-52.

161. Frances R, Chiva M, Sanchez E, et al. Bacterial translocation is downregulated by anti-TNF-alpha monoclonal antibody administration in rats with cirrhosis and ascites. $J$ Hepatol 2007:46:797-803

162. Adawi D, Kasrawi FB, Molin G, et al. Effect of lactobacillus supplementation with and without arginine on liver damage and bacterial translocation in an acute liver injury model in the rat. Hepatology 1997;25:642-7.

163. Wang XD, Soltesz V, Molin G, et al. The role of oral administration of oatmeal fermented by Lactobacillus reuteri R2LC on bacterial translocation after acute liver failure induced by subtotal liver resection in the rat. Scand J Gastroenterol 1995;30:180-5.

164. Liu 2, Duan ZP, Ha DK, et al. Synbiotic modulation of gut flora: effect on minimal hepatic encephalopathy in patients with cirrhosis. Hepatology 2004;39:1441-9.

165. Rayes N, Seehofer D, Theruvath T, et al. Supply of pre- and probiotics reduces bacterial infection rates after liver transplantation-a randomized, double-blind trial. Am J Transplant 2005:5:125-30. 


\section{GUT Spontaneous bacterial peritonitis: recent guidelines and beyond}

R Wiest, A Krag and A Gerbes

Gut 2012 61: 297-310 originally published online December 6, 2011 doi: 10.1136/gutjnl-2011-300779

Updated information and services can be found at:

http://gut.bmj.com/content/61/2/297

\section{These include:}

References This article cites 159 articles, 14 of which you can access for free at: http://gut.bmj.com/content/61/2/297\#BIBL

\section{Email alerting} service

Receive free email alerts when new articles cite this article. Sign up in the box at the top right corner of the online article.

ErrataAn erratum has been published regarding this article. Please see next page or:

http://gut.bmj.com/content/61/4/636.full.pdf

Topic Articles on similar topics can be found in the following collections Collections

Gut Education (56)

GUT Recent advances in clinical practice (71)

Hepatic cancer (436)

Cirrhosis (312)

\section{Notes}

To request permissions go to:

http://group.bmj.com/group/rights-licensing/permissions

To order reprints go to:

http://journals.bmj.com/cgi/reprintform

To subscribe to BMJ go to:

http://group.bmj.com/subscribe/ 
in situ hybridisation, the authors found bacteria deeply infiltrating the appendix. Fusobacteria (mainly Fusobacterium nucleatum/necrophorum) were specific components of epithelial and submucosal infiltrates in $62 \%$ of patients and were not found in various controls. The presence of Fusobacteria correlated positively with the severity of appendicitis. Conversely, main faecal microbiota including Faecalibacterium prausnitzii groups were significantly decreased with an inverse relationship with the severity of the disease. ${ }^{1}$

Altogether, these observations point to the presence of a local appendiceal dysbiosis with more bacteria with inflammatory properties and fewer bacteria with antiinflammatory properties associated with acute appendicitis. The genus Fusobacterium is characterised by high proteolytic activity and comprises different distinct species. The most frequently encountered is $F$ nucleatum, which is frequent in the oral sphere and implicated in periodontitis. F necrophorum has a high pathogenic potential and is implicated in life-threatening infections such as Lemierre's syndrome. In cattle, it is found in footrot disease and is also frequent in liver abscesses. The third important species is $F$ varium. All species are part of the normal intestinal microflora. By contrast, $F$ prausnitzii, which showed decreased numbers in appendicitis, is a bacterium with antiinflammatory properties. Its numbers are also reduced in patients with inflammatory bowel disease and it is associated with postoperative recurrence of Crohn's disease. ${ }^{2}$

Over 30 studies have now analysed the association between appendectomy and ulcerative colitis (UC) and the majority of the studies support a highly significant inverse relationship. ${ }^{3}$ It is also well established that the protective effect of appendectomy depends on the inflammatory conditions (appendicitis or lymphadenitis) that were the indication for appendectomy rather than on appendectomy itself. ${ }^{4}$ The available data regarding whether or not appendectomy performed after the onset of UC can modulate its clinical course arey still limited and conflicting and properly controlled trials are needed. ${ }^{5}$ Despite accumulating clinical evidence, the mechanism linking appendicitis, appendectomy and UC remains elusive.

Interestingly, a link between Fusobacteria and UC has been reported in several studies. In 2002, F varium was reported to be present in the colonic mucosa of a high proportion (84\%) of UC patients. ${ }^{6}$ Using immunoblotting with a $F$ varium antigen Minami et al found positive signals with sera from 45 $(40.2 \%)$ of 112 UC patients versus 20 $(15.6 \%)$ of 128 healthy controls $(p<0.01)$. Seropositive UC patients were more likely to have clinically severe disease than seronegative UC patients and the disease location in seropositive patients was more extensive than in seronegative patients. ${ }^{7}$
Finally, a 2-week triple antibiotic therapy to which $F$ varium is susceptible (tetracycline, metronidazole and amoxicillin) produced improvement, remission and steroid withdrawal in active UC more effectively than a placebo. ${ }^{8}$

In conclusion, the development of an appendiceal dysbiosis may be a priming event in the occurrence of UC. The removal of the appendix may reduce the risk of further development of UC in genetically susceptible individuals. We believe that this hypothesis should be further explored in studies examining the protective role of appendicitis and appendectomy in UC.

\section{Roblin, ${ }^{1}$ C Neut, ${ }^{2}$ A Darfeuille-Michaud, ${ }^{3}$ J F Colombel ${ }^{4,5}$}

${ }^{1}$ Department of Hepato-Gastroenterology, University Hospital of Saint-Etienne, Saint-Etienne, France; ${ }^{2}$ Laboratoire de Bacteriologie, Faculte de Pharmacie et INSERM U995, Universite Lile Nord de France, Lille, France; ${ }^{3}$ Clermont Université, Université d'Auvergne, Jeune Equipe, Clermont-Ferrand, France; ${ }^{4}$ Department of Hepatogastroenterology and INSERM U995, Universite Lille Nord de France, Lille, France; ${ }^{5}$ Mount Sinai Medical School of Medicine, New York, New York, USA

Correspondence to $\operatorname{Dr} X$ Roblin, Department of Hepato-Gastroenterology, University Hospital of SaintEtienne, Saint-Etienne, France;

xavier.roblin@chu-st-etienne.fr

\section{Competing interests None.}

Provenance and peer review Not commissioned; internally peer reviewed.

Published Online First 7 July 2011

Gut 2012;61:635-636. doi:10.1136/gutjnl-2011-300576

\section{REFERENCES}

1. Swidsinski A, Dörffel $Y$, Loening-Baucke $V$, et al. Acute appendicitis is characterised by local invasion with Fusobacterium nucleatum/necrophorum. Gut 2011;60:34-40.

2. Sokol H, Pigneur B, Watterlot L, et al. Faecalibacterium prausnitzii is an anti-inflammatory commensal bacterium identified by gut microbiota analysis of Crohn disease patients. Proc Natl Acad Sci 2008;105:16731-6.

3. Andersson RE, Olaison G, Tysk C, et al. Appendectomy and protection against ulcerative colitis. N Engl J Med 2001;344:808-14.

4. Frisch M, Pedersen BV, Andersson RE. Appendicitis, mesenteric lymphadenitis, and subsequent risk of ulcerative colitis: cohort studies in Sweden and Denmark. BMJ 2009;338:b716.

5. Cosnes J, Carbonnel F, Beaugerie L, et al. Effects of appendicectomy on the course of ulcerative colitis. Gut 2002;51:803-7.

6. Ohkusa T, Sato N, Ogihara T, et al. Fusobacterium varium localized in the colonic mucosa of patients with ulcerative colitis stimulates species-specific antibody. J Gastroenterol Hepatol 2002;17:849-53.

7. Minami M, Ando T, Okamoto A, et al. Seroprevalence of Fusobacterium varium in ulcerative colitis patients in Japan. FEMS Immunol Med Microbiol 2009:56:67-72.

8. Ohkusa T, Kato K, Terao S, et al. Newly developed antibiotic combination therapy for ulcerative colitis: a double-blind placebo-controlled multicenter trial. Am J Gastroenterol 2010:105:1820-9.

\section{CORRECTION}

doi:10.1136/gutjnl-2011-300779corr1

Wiest R, Krag A, Gerbes A. Spontanous bacterial peritonitis: recent guidelines and beyond. Gut 2012;61:297-310. doi:10.1136/ gutjnl-2011-300779

Unfortunately, references have been misplaced and/or omitted in this paper, and the following citations should be used:

1. European Association for the Study of the Liver. EASL clinical practice guidelines on the management of ascites, spontaneous bacterial peritonitis, and hepatorenal syndrome in cirrhosis. $J$ Hepatol 2010;53:397-417.

2. Garcia-Tsao G, Lim JK. Management and treatment of patients with cirrhosis and portal hypertension: recommendations from the Department of Veterans Affairs Hepatitis C Resource Center Program and the National Hepatitis C Program. Am J Gastroenterol 2009;104:1802-29.

3. Gerbes AL, Gulberg V, Sauerbruch $\mathrm{T}$, et al. [German S 3-guideline "ascites, spontaneous bacterial peritonitis, hepatorenal syndrome"]. Z Gastroenterol 2011;49(6):749-79.

On page 302 , in the last paragraph, the correct citations for references 108 and 110 (not given in the reference list) should be respectively:

108. Sort P, Navasa M, Arroyo V, et al. Effect of intravenous albumin on renal impairment and mortality in patients with cirrhosis and spontaneous bacterial peritonitis. $N$ Engl J Med 1999:341:403-9.

110. Chen TA, Tsao YC, Chen A, et al. Effect of intravenous albumin on endotoxin removal, cytokines, and nitric oxide production in patients with cirrhosis and spontaneous bacterial peritonitis. Scand J Gastroenterol 2009;44:619-25.

The citations given in table 2 are not correctly reflected in the reference list and hence, please refer to author and year to identify the corresponding investigation.

Finally, the most valuable investigation by Fernandez et al has meanwhile been accepted for publication (Fernandez J, et al. Hepatology 2011 Dec 20. doi:10.1002/hep.25532. [Epub ahead of print]). Therefore, this citation should be used in table 1 and at each place where a personal communication with either JG Acevedo or J Fernandez is stated in the text. 